\title{
Nutritious Biscuits for Celiac Patients: Effect of Different Cereals and Legumes Blends
}

\author{
Hamid M. Ziena, ${ }^{1}$ Shrief M. Shamsia ${ }^{1}$, Saad A. Mahgoub ${ }^{2}$ and Mohamed A. Emara ${ }^{2}$
}

\begin{abstract}
This study was aimed to prepare and evaluate some biscuit products as gluten free products (GFPs) for Celiac disease (CD) patient. Four biscuits including control and three treatments according to raw material content have been prepared. The control $\left(100 \%\right.$ wheat flour), $B_{1}(45 \%$ yellow corn flour, $35 \%$ faba bean flour and $20 \%$ corn starch), $B_{2}$ (45\% broken rice flour, $35 \%$ chickpea flour and $20 \%$ corn starch) and $B_{3}(45 \%$ sorghum flour, $35 \%$ lima bean flour and $20 \%$ corn starch). Chemical composition, mineral content, anti-nutritional factors in addition to sensory properties were evaluated. The results revealed that crude protein contents of different products were 8.29, 9.62, 7.52 and $8.18 \mathrm{~g} / 100 \mathrm{~g}$ for control, products $B_{1}, B_{2}$ and $B_{3}$, respectively. Potassium was the predominant minerals especially in product $\left(B_{2}\right)$, which contained the highest contents of potassium $(353.47 \mathrm{mg} / 100 \mathrm{~g})$ and sodium $(32.71$ $\mathrm{mg} / \mathbf{1 0 0 g}$ ). Phytic acid was ranged from 17.53 to $100.53 \mathrm{mg} / 100 \mathrm{~g}$ and tannins were ranged from 5.04 to 10.90 $\mathrm{mg} / 100 \mathrm{~g}$. Germination, boiling, drying of raw materials and backing process caused increased of protein digestibility, eliminated of anti-nutritional factors and enhanced sensory and nutritional quality. According to sensory evaluation all GFB products were improved significantly compared to control product.
\end{abstract}

Keywords: Gluten free products, Pretreatment of cereals and legumes, Biscuits, Chemical composition, Sorghum, Broken rice, Yellow corn, Chickpea, Faba bean and lima bean.

\section{INTRODUCTION}

Celiac disease is defined as an immune-mediated enteropathy induced by exposure to dietary gluten which is defined as the material that can be separated from wheat flour when starch, and other minor components, are removed by washing under running water (Cann and Day, 2013). Gliadin is the causative agent in wheat while other prolamins are the causative agents in rye (secalin), oat (avenin), barley (hordein) maize (zeins), rice (oryzins), and (kafirins) of millet and sorghum (Badiu et al., 2014). CD, the body's immune system responds abnormally to gluten, resulting in inflammation of the intestinal villi caused by antibodies that fight against the presence of glutamine and the subsequent enzyme transglutaminase in the small intestine (Badiu et

DOI: 10.21608 /ASEJAIQJSAE.2019.36524

${ }^{1}$ Food and Dairy Science and Technology Dept., Faculty of Agriculture, Damanhur University.

${ }^{2-C}$ Crops Technology Research Dept. Food Technology Research Institute, Agriculture Research Center, Giza, Egypt.

Received May 25, 2019, Accepted June 23, 2019 al., 2014). With the continuous inflammation of intestinal mucosa and villous atrophy, it causes of damage to the lining of the small intestine, and reduced absorption of iron, calcium, vitamins A, D, E, K, and folate (Rosell and Garzon, 2015). The mainstay of treatment for $\mathrm{CD}$ is a stricte lifelong adherence to a GFD (Lee et al., 2007). Gluten plays a principal role in backed development by giving cohesiveness and promoting the retention of the $\mathrm{CO}_{2}$ produced during fermentation. Thus, gas expansion causes breads to gain volume and attain acceptable crumb texture (Deora et al., 2014). Because it contains two major protein fractions: glutenin (a rough rubbery mass when fully hydrated) and gliadin (a viscous fluid mass) Many of the commercial GFPs are made from one or more ingredients which do not contain gluten such as some legumes (faba bean, chickpea and lima bean), and some cereals (rice, corn and sorghum) (Giménez et al., 2013).

Fabian and $\mathrm{Ju}$ (2011) reported that rice flour is recommended for use in GFPs processing instead of wheat flour because it possesses no gluten. While Masure et al. (2016) showed that the most commonly to obtain an acceptable GFP are yellow corn flour after rice flour. Also Ciacci et al. (2007) noticed that sorghum is the fifth largest crop produced worldwide and has been shown to be safe for people with CD. Giuberti et al. (2015) noticed that faba bean flour enhance nutritional properties of gluten free products. Where Polesi et al. (2011) postulated that chickpea starch presents a similar amount of amylose as wheat, and were already used as an ingredient in GFP. Cai et al. (2003) mentioned that lima bean able to enhance the nutritional properties of GFP (Campos et al., 2010).

This study aimed to prepare and evaluate biscuit products as GFPs for CD patient. Four biscuits included control and three treatments according to raw material contents have been prepared. These products were prepared based on the local available pretreated ingredients such as cereals (yellow corn flour - broken rice flour - sorghum flour) and legumes (chickpeas flour - faba bean flour - lima bean flour). Chemical composition, mineral content, anti-nutritional factors in 
addition to sensory properties were evaluated in the products to achieve the main goal of this study.

\section{MATERIALS AND METHODS}

\section{Materials:}

Yellow corn (Zea mays, L.) varieties Giza 162, sorghum (Sorghum bicolor, L.) varieties Giza 15, chickpea (Cicer arietinum, L) variety Giza 131, lima bean (Phaseolus lunatus L.) varieties Giza 6 and faba bean (Vicia faba, L.) varieties Giza 461 were obtained from Field Crops Research Institute, Agricultural Research Center Giza- Egypt. While broken rice was obtained from rice polishing company, Beheira governorate, Egypt.

\section{Methods:}

\section{Preparation of raw materials}

Yellow corn, sorghum and broken rice grains were cleaned physically to eliminate dust particles, seeds of other crops and other contaminants like as weeds and metals, and then milled in the laboratory mill (Brabender Duisburg, Germany). Chickpeas, faba bean and lima bean were cleaned from the impurities, soaked for $12 \mathrm{hr}$. and germinated for 3 day at $\left(25^{\circ} \mathrm{C}\right)$ according to the method of (Sidky et al., 1991). After germination procedure taking place germinated chickpeas, faba bean and lima bean were cooked separctely in boiling water for $15 \mathrm{~min}$, and they dehulled by hand and drying in oven at $\left(40^{\circ} \mathrm{C}\right)$ for $24 \mathrm{hr}$. then milled in a laboratory mill (Brabender Duisburg, Germany). All dried samples were passed through 60 mesh screen and stored in polyethylene bags in deep freezer at $-20^{\circ} \mathrm{C}$ until used (El-Adawy, 2002)

\section{Preparation of formulas:}

Four formulas were prepared using the previous ingredients. These ingredients and their amounts are illustrated in Table (1).

\section{Biscuit baking procedure}

The biscuits dough was prepared as follow: $35 \%$ powdered sugar, $2 \%$ dry egg and $35 \%$ shortening were mixed for 2 min at speed four using a mixer (model SM-
5D, China Sinma Machine). The dry ingredients (flour as in Table 1, baking powder $3 \%$, salt $1 \%$ and vanillin $1 \%$ ) were weighed and mixed with $10 \%$ milk for $3 \mathrm{~min}$ at speed 3 to get biscuit dough. Then, it was sheeted to a thickness of about $5 \mathrm{~mm}$; the sheeted dough was cut into square shape using a $35 \mathrm{~mm}$ diameter. The biscuits dough was baked at $180^{\circ} \mathrm{C}$ for $12-15 \mathrm{~min}$. Biscuits were kept at room temperature for 8-10 minutes after baking befor sensory evaluation, Obeidat et al. (2012). The reset of biscuits were kept in polyethylene bags at refrigerator $\left(4^{\circ} \mathrm{C}\right)$ until physical and chemical analyses.

\section{Chemical analysis:}

Moisture, crude protein, crude fat, ash and crude fiber were determined according to the official methods of AOAC (2005). Total carbohydrates were calculated by difference. In vitro digestibility of protein was determined by successive pepsin trypsin enzyme system according to method of Chavan et al. (2001). Minerals were determined using Perkin Elmer (Model 3300, USA) Atomic Absorption Spectrophotometer according to AOAC (2005). Trypsin inhibitor activity was assayed by the method of Gatta et al. (1988). Phytate was extracted and determined according to the procedure described by Camire and Clydesdole (1982) as modified by Mohamed et al. (1986). Tannins were determined using vanillin hydrochloric acid method as described by Burn (1971).

\section{Organoleptic evaluation of biscuit products:}

Sensory evaluations of biscuits were carried out by panel of 15 experienced guides from the staff of the Food Tech. Res. Institute, Agric., Res. Center, Giza, Egypt. Assigning scores for various quality attributes such as appearance, color, flavor, texture, taste and overall acceptability were done using 9-point hedonic $\operatorname{scale}(1=$ disliked extremely, to $9=$ like extremely $)$ Chinma et al, (2012).

\section{Statistical analysis}

Statistical analysis was carried out according to Fisher (1970). (LSD) Least significant difference test was used to compare the significant differences between means of treatments (Waller and Duncan, 1969).

Table 1.Main ingredients of biscuit formulas

\begin{tabular}{|c|c|c|c|c|}
\hline \multirow{2}{*}{ Ingredients } & Control formula & Formula. $\left(\mathbf{B}_{1}\right)$ & Formula. $\left(\mathbf{B}_{2}\right)$ & Formula.(B $\left.\mathbf{B}_{3}\right)$ \\
\hline & $\%$ & $\%$ & $\%$ & $\%$ \\
\hline Wheat & 100 & --- & --- & --- \\
\hline Yellow corn & --- & 45 & --- & --- \\
\hline Sorghum & --- & --- & --- & 45 \\
\hline Broken rice & --- & --- & 45 & --- \\
\hline Faba bean & --- & 35 & --- & --- \\
\hline Chickpea & --- & --- & 35 & --- \\
\hline Lima bean & --- & & & 35 \\
\hline Maize starch & --- & 20 & 20 & 20 \\
\hline
\end{tabular}




\section{RESULTS AND DISCUSSION}

\section{Proximate chemical composition and protein digestibility of biscuit products}

Biscuit products were analyzed for determining proximate composition and the data were presented in Table (2). The results were significantly different. The result showed that the moisture content was between $5.30-6.40 \%$. Control product contained the highest content of carbohydrate compared with all other products, it was in the second order of protein digestibility, but it had the lowest content of crude fat $(12.18 \%)$ and ash content $(0.79 \%)$. Product $\mathrm{B}_{1}$ recorded considerable amounts of crude fat $(14.64 \%)$, crude fiber $(2.06 \%)$ and crude protein $(9.62 \%)$, but it had the lowest values of the total carbohydrates $(66.99 \%)$, moisture $(5.30 \%)$ and protein digestibility (79.04). Whereas, product $B_{2}$ contained the highest value of protein digestibility $(86.35 \%)$ due to it's containing of rice flour, but it had the lowest contents of crude protein $(7.52 \%)$ and crude fiber $(1.25 \%)$. Product $\mathrm{B}_{3}$ contained the highest contents of moisture and ash, it characterized by the high content of fat (14.50\%). Adebayo and Okoli (2017) found that the addition of lima flour to cereals has enhanced the nutritional composition of the biscuits. These results were agreed with Sharoba et al. (2014) who reported that in biscuit products crude protein content was ranged from 8.00 to $10.35 \%$, crude fat ranged from 8.00 to $11.00 \%$, ash content ranged from 1.50 to $4.20 \%$ and crude fiber ranged from 0.70 to $2.92 \%$.

From the same Table 2 it could be noticed that crude protein content ranged from $7.52 \%$ to $9.62 \%$, carbohydrates content ranged from $66.99 \%$ to $70.96 \%$, crude fat content ranged from $12.18 \%$ to $14.64 \%$, crude fiber content ranged from $1.25 \%$ to $2.06 \%$ and ash content ranged from $0.79 \%$ to $1.73 \%$. These results were similar to the biscuit composition presented by Sakac et al. (2015) and Mohammad (2017) who conducted a study on production of high nutritional value biscuit from broken rice supplemented with some legumes flour and found that the chemical composition of its biscuit product was $6.49 \%$ for moisture, $8.85 \%$ for protein, $26.3 \%$ for fat, $0.5 \%$ for ash and $0.48 \%$ for fiber.

\section{Mineral contents of biscuit products}

Biscuit products were analyzed to determine mineral contents and the data are presented in Table (3). The results were significantly different. Data revealed that all products had higher content of macro elements than control product. Kupper (2005) reported that there was a risk of nutritional deficiencies in the group of people with celiac disease that were following gluten-free diet. The risk was applied mainly to insufficient intake of calcium, iron, zinc and selenium. Potassium was the main element in the all biscuit products, and it was the predominant minerals especially in product $\mathrm{B}_{2}$, which contained the highest contents of potassium (353.47 $\mathrm{mg} / 100 \mathrm{~g})$ and sodium $(32.71 \mathrm{mg} / 100 \mathrm{~g})$. Control product characterized by the highest content of zinc (1.90 $\mathrm{mg} / 100 \mathrm{~g}$ ), but it had the lowest content of all macro elements. While product $\mathrm{B}_{1}$ contained high content of macro elements, but it had the lowest content of iron $(1.84 \mathrm{mg} / 100 \mathrm{~g})$. Product $\mathrm{B}_{3}$ recorded the highest content of calcium, magnesium and iron $(81.73 \mathrm{mg} / 100 \mathrm{~g})$, $(103.30 \mathrm{mg} / 100 \mathrm{~g})$ and $(2.95 \mathrm{mg} / 100 \mathrm{~g})$, respectively, but it had the lowest content of zinc $(1.20 \mathrm{mg} / 100 \mathrm{~g})$. The noticed increment of important minerals in biscuit products was as result of mixing some cereals and some legumes. These results were in agreement with Priscila et al. (2015) they showed that the minerals content of biscuit which made from legume blended with rice flour had $3.31 \mathrm{mg} / 100 \mathrm{gm}$ iron and $1.78 \mathrm{mg} / 100 \mathrm{gm}$ zinc.

From the same Table it could be observed that sodium content ranged from 7.92 to $32.71 \mathrm{mg} / 100 \mathrm{~g}$, potassium content ranged from 210.22 to 353.47 $\mathrm{mg} / 100 \mathrm{~g}$, calcium content ranged from 22.71 to 81.73 $\mathrm{mg} / 100 \mathrm{~g}$, magnesium content ranged from 53.85 to $103.30 \mathrm{mg} / 100 \mathrm{~g}$, iron content ranged from 1.84 to 2.95 $\mathrm{mg} / 100 \mathrm{~g}$ and zinc ranged from 1.20 to $1.90 \mathrm{mg} / 100 \mathrm{~g}$.

Table 2. Proximate chemical composition and protein digestibility of biscuit products (\% as wet basis)*

\begin{tabular}{lccccc}
\hline Parameters & control & $\mathbf{B}_{1}$ & \multicolumn{1}{c}{$\mathbf{B}_{2}$} & $\mathbf{B}_{3}$ & LSD 0.05 \\
\hline Moisture & $5.92 \pm 0.16^{\mathrm{ab}}$ & $5.30 \pm 0.23^{\mathrm{b}}$ & $6.29 \pm 0.21^{\mathrm{a}}$ & $6.40 \pm 0.23^{\mathrm{a}}$ & 0.70 \\
Crude protein & $8.29 \pm 0.02^{\mathrm{b}}$ & $9.62 \pm 0.03^{\mathrm{a}}$ & $7.52 \pm 0.07^{\mathrm{c}}$ & $8.18 \pm 0.02^{\mathrm{b}}$ & 0.14 \\
Crude fat & $12.18 \pm 0.44^{\mathrm{b}}$ & $14.64 \pm 0.35^{\mathrm{a}}$ & $12.99 \pm 0.08^{\mathrm{b}}$ & $14.50 \pm 0.62^{\mathrm{a}}$ & 1.38 \\
Ash & $0.79 \pm 0.03^{\mathrm{d}}$ & $1.39 \pm 0.04^{\mathrm{b}}$ & $1.09 \pm 0.06^{\mathrm{c}}$ & $1.73 \pm 0.05^{\mathrm{a}}$ & 0.16 \\
Crude fiber & $1.86 \pm 0.08^{\mathrm{a}}$ & $2.06 \pm 0.09^{\mathrm{a}}$ & $1.25 \pm 0.07^{\mathrm{c}}$ & $1.54 \pm 0.04^{\mathrm{b}}$ & 0.24 \\
Carbohydrate & 70.96 & 66.99 & 70.86 & 67.65 & \\
( by difference) & $84.19 \pm 0.65^{\mathrm{b}}$ & $79.04 \pm 0.25^{\mathrm{c}}$ & $86.35 \pm 0.53^{\mathrm{a}}$ & $83.33 \pm 0.52^{\mathrm{b}}$ & 1.67 \\
Protein digestibility & & & & \\
\hline
\end{tabular}

*Means in a column not sharing the same superscript are significantly different at $\mathrm{p}<0.050$. 
Table 3. Mineral contents of different biscuit products (mg/100g as wet basis)*

\begin{tabular}{cccccc}
\hline Minerals & Control & $\mathbf{B}_{1}$ & $\mathbf{B}_{2}$ & B $_{3}$ & LSD 0.05 \\
\hline Sodium & $7.92 \pm 0.43^{\mathrm{d}}$ & $18.71 \pm 0.24^{\mathrm{c}}$ & $32.71 \pm 2.09^{\mathrm{a}}$ & $27.97 \pm 1.42^{\mathrm{b}}$ & 4.21 \\
Potassium & $210.22 \pm 8.30^{\mathrm{c}}$ & $320.28 \pm 14.08^{\mathrm{ab}}$ & $353.47 \pm 9.05^{\mathrm{a}}$ & $314.78 \pm 12.51^{\mathrm{b}}$ & 36.68 \\
Calcium & $22.71 \pm 0.98^{\mathrm{d}}$ & $71.43 \pm 2.02^{\mathrm{b}}$ & $59.77 \pm 1.56^{\mathrm{c}}$ & $81.73 \pm 1.51^{\mathrm{a}}$ & 4.96 \\
Magnesium & $53.85 \pm 2.65^{\mathrm{c}}$ & $77.53 \pm 3.41^{\mathrm{b}}$ & $66.70 \pm 4.06^{\mathrm{b}}$ & $103.30 \pm 3.37^{\mathrm{a}}$ & 11.13 \\
Iron & $2.39 \pm 0.20^{\mathrm{b}}$ & $1.84 \pm 0.04^{\mathrm{c}}$ & $2.42 \pm 0.14^{\mathrm{b}}$ & $2.95 \pm 0.04^{\mathrm{a}}$ & 0.42 \\
Zinc & $1.90 \pm 0.07^{\mathrm{a}}$ & $1.36 \pm 0.04^{\mathrm{b}}$ & $1.80 \pm 0.07^{\mathrm{a}}$ & $1.20 \pm 0.06^{\mathrm{b}}$ & 0.21 \\
\hline
\end{tabular}

*Means in a column not sharing the same superscript are significantly different at $\mathrm{p}<0.050$.

These results were in agreement with Mohammad (2017), who found that the mineral contents of biscuit were iron $(1.69 \mathrm{mg} / 100 \mathrm{gm})$, zinc $(1.86 \mathrm{mg} / 100 \mathrm{gm})$, magnesium $(62.50 \mathrm{mg} / 100 \mathrm{gm})$ and calcium (119 $\mathrm{mg} / 100 \mathrm{gm})$.

\section{Anti-nutritional factors of biscuit products}

The results of anti-nutritional factors in biscuit products are presented in Table (4).The results showed significant differences between total phytic acid, tannins or trypsin inhibitor contents in resultant different biscuit products. It could be noticed that control product contained the highest amount of total phytic acid $(100.53 \mathrm{mg} / 100 \mathrm{~g})$ and tannin $(10.90 \mathrm{mg} / 100 \mathrm{~g})$ compounds, but it was free of trypsin inhibitor, while product $\mathrm{B}_{1}$ and $\mathrm{B}_{2}$ contained low amounts of phytic acid and total tannins compared with other products. Tannins are known to present in food legumes that decrease the protein quality of foods and interfere with dietary iron absorption (Tadelel, 2015). Product $\mathrm{B}_{2}$ contained the highest amount of trypsin inhibitor $(0.28 \mathrm{TIU} / \mathrm{mg})$, but it had the lowest contents of phytic acid (17.53 $\mathrm{mg} / 100 \mathrm{~g})$ and tannins $(5.04 \mathrm{mg} / 100 \mathrm{~g})$. On the other hand, product $\mathrm{B}_{3}$ was in the second order in phytic acid and tannins contents. These results were agreed with Hawa et al. (2018). Phytate content is high in legumes and decreases the bioavailability of essential minerals and bioavailability of proteins by forming insoluble phytate-mineral and phytate protein complexes (Admassu, 2009).

It was clear that germination followed by boiling and drying of raw materials and backing process decreased the anti-nutritional factors, where the reduction ratios were: trypsin inhibitor ( 81 to $83 \%$ ), phytic acid (58-68
$\%$ ) and tannins (72-76\%). According to Adeparusi (2001), tannins affect protein digestibility and adversely influence the bioavailability, obtained from plant sources lead to poor iron and calcium absorption.

\section{Organoleptic evaluation of biscuit products}

The sensory evaluation of biscuit products were performed for appearance, color, taste, texture, flavor and overall acceptability (out of 9). Scores for sensory attributes of biscuit as fresh products are presented in Tables (5). There was significant difference between treatments in the all properties. Taste is the primary factor that determines the acceptability of any product which has the highest impact as far as market success of product is concerned. The results revealed that product $\mathrm{B}_{1}$ had the highest value of taste followed by control product then product $\mathrm{B}_{2}$. Control product had the highest value of overall acceptability followed by products $B_{1}$ then $B_{2}$.

Results in Table (5) for sensory evaluation of fresh products showed that control product and products $\mathrm{B}_{1}$ and $\mathrm{B}_{2}$ were excellent; while control had the highest overall acceptability (8.06), color, texture and flavor. While product $B_{1}$ was in the second order of overall acceptability (7.86), it had the highest value of appearance, taste and texture this may be related to its contents of yellow corn flour. Product $\mathrm{B}_{2}$ was excellent in color (8.53) this may be related to its contents of rice flour and chickpeas flour. Color is a very important tool in judging properly baked products, which not only reflect the suitable raw materials used for the preparation but also provides information about the formulation and quality of the product (Ojinnaka et al., 2013).

Table 4. Anti-nutritional factors contents of biscuit products (as wet basis)*

\begin{tabular}{lccc}
\hline Product & $\begin{array}{c}\text { Trypsin inhibitor } \\
\text { TIU/mg }\end{array}$ & $\begin{array}{c}\text { Phytic acid } \\
(\mathbf{m g} / \mathbf{1 0 0 g})\end{array}$ & $\begin{array}{c}\text { Tannins } \\
(\mathbf{m g} / \mathbf{1 0 0 g})\end{array}$ \\
\hline Control & $0.00 \pm 0.00^{\mathrm{c}}$ & $100.53 \pm 5.60^{\mathrm{a}}$ & $10.90 \pm 0.44^{\mathrm{a}}$ \\
$\mathrm{B}_{1}$ & $0.13 \pm 0.00^{\mathrm{b}}$ & $29.86 \pm 2.25^{\mathrm{c}}$ & $5.46 \pm 0.32^{\mathrm{c}}$ \\
$\mathrm{B}_{2}$ & $0.28 \pm 0.01^{\mathrm{a}}$ & $17.53 \pm 1.00^{\mathrm{c}}$ & $5.04 \pm 0.11^{\mathrm{c}}$ \\
$\mathrm{B}_{3}$ & $0.12 \pm 0.00^{\mathrm{b}}$ & $61.63 \pm 6.42^{\mathrm{b}}$ & $9.69 \pm 0.27^{\mathrm{b}}$ \\
LSD 0.05 & 0.03 & 14.47 & 1.02 \\
\hline
\end{tabular}

*Means in a column not sharing the same superscript are significantly different at $\mathrm{p}<0.050$. 
Table 5. Sensory evaluation of the biscuit products

\begin{tabular}{lccccc}
\hline Properties & Control & $\mathbf{B}_{1}$ & $\mathbf{B}_{2}$ & $\mathbf{B}_{3}$ & LSD 0.05 \\
Appearance & $8.13 \pm 0.21^{\mathrm{a}}$ & $8.26 \pm 0.20^{\mathrm{a}}$ & $7.93 \pm 0.26^{\mathrm{a}}$ & $6.66 \pm 0.31^{\mathrm{b}}$ & 0.72 \\
color & $7.86 \pm 0.25^{\mathrm{ab}}$ & $7.66 \pm 0.28^{\mathrm{b}}$ & $8.53 \pm 0.13^{\mathrm{a}}$ & $6.13 \pm 0.37^{\mathrm{c}}$ & 0.78 \\
Taste & $8.00 \pm 0.27^{\mathrm{ab}}$ & $8.06 \pm 0.24^{\mathrm{a}}$ & $7.40 \pm 0.40^{\mathrm{ab}}$ & $7.00 \pm 0.40^{\mathrm{b}}$ & 0.96 \\
texture & $8.06 \pm 0.24^{\mathrm{a}}$ & $8.06 \pm 0.28^{\mathrm{a}}$ & $7.60 \pm 0.33^{\mathrm{a}}$ & $7.33 \pm 0.33^{\mathrm{a}}$ & 0.85 \\
Flavor & $8.06 \pm 0.30^{\mathrm{a}}$ & $7.86 \pm 0.23^{\mathrm{ab}}$ & $7.40 \pm 0.36^{\mathrm{ab}}$ & $7.00 \pm 0.29^{\mathrm{b}}$ & 0.85 \\
Overall acceptability & $8.06 \pm 0.22^{\mathrm{a}}$ & $7.86 \pm 0.21^{\mathrm{a}}$ & $7.56 \pm 0.35^{\mathrm{ab}}$ & $6.80 \pm 0.40^{\mathrm{b}}$ & 0.88 \\
\hline
\end{tabular}

*Means in a column not sharing the same superscript are significantly different at $p<0.050$.
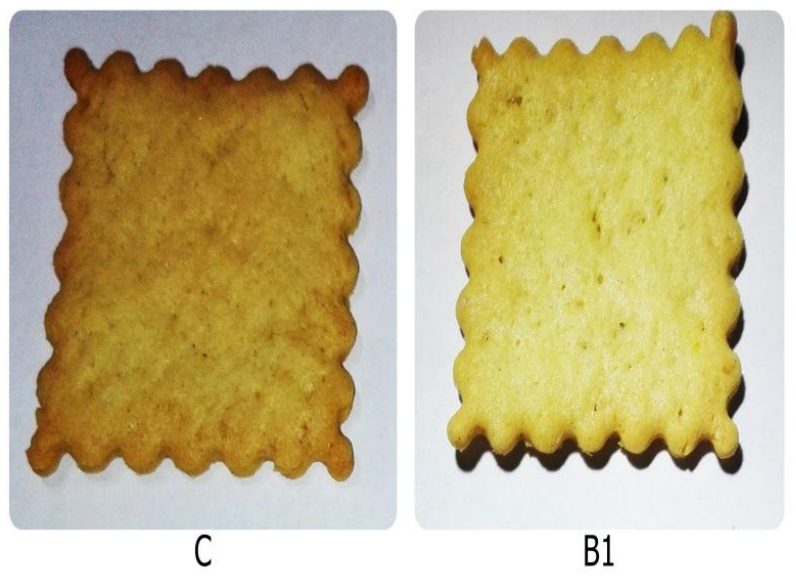

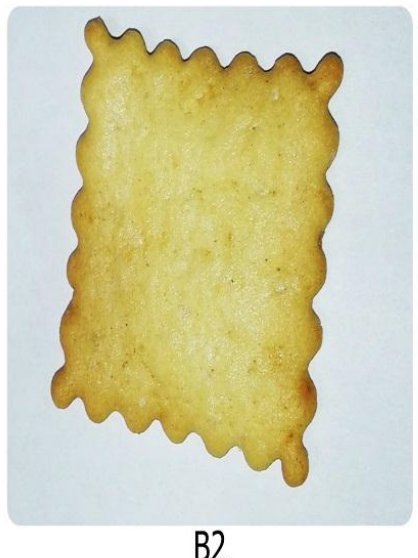

B2

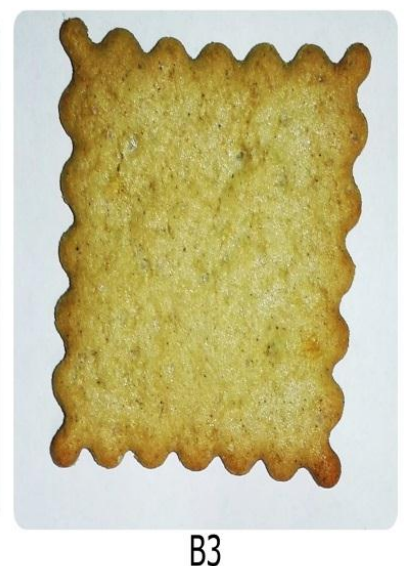

B3

Figure 1. Different biscuit products

\section{CONCLUSION}

Gluten free biscuit products prepared from mixing of some cereals and legumes are considerd a valuable addition for celiac patient. Some technological treatments e.g. germination, boiling, drying and backing process are recommended to enhance the nutritional characteristics and reduce the anti-nutritional factors of the products.

\section{REFERENCES}

Adebayo, S. F. and E. C. Okoli. 2017. Production and evaluation of biscuits from lima bean (Phaseolus Lunatus), sorghum and wheat flour blends. Journal of Environmental Science, Toxicology and Food Technology 11(7):2319-2402

Adeparusi, E. O. 2001. Effect of processing on the nutrients and anti-nutrients of lima bean (Phaseolus lunatus L.) flour. Die Nahrung 45(2): 94-96.

Admassu, S. 2009. Potential health benefits and problems associated with phytochemicals in food legumes. East African Journal of Sciences 3(2): 116-133.

AOAC. 2005 Official Methods of Analysis. Association of Official Analytical Chemists. Washington DC:

Badiu, E., I. Aprodu and I. Banu.2014. Trends in the development of gluten-free bakery products. Food Technol. 38:21-36
Burn,R.E. 1971. Methods for estimation of tannin in grain sorghum. Agron. J., 63:511-512.

Cai, R., N. S. Hettiarachchy and J. Jalaluddin. 2003. High performance liquid chromatography determination of phenolic constituents in 17 varieties of cowpeas. Journal of Agricultural and Food Chemistry. 51:1623-1627.

Camire, A. L. and M. Clydesdole. 1982. Analysis of phytic acid in food by HPLC. J. Food Sci. 47:575-578.

Campos, V. R., P. G. Loarca and B. D. Oomah. 2010. Minor components of pulses and their potential impact on human health. Food Research International, 43: 461-482.

Cann, T.H. and L. Day. 2013. Effect of sodium chloride on gluten network formation dough micro structure and rheology in relation to bread making. J. Cereal Sci. 57:444-452.

Chavan, U. D., D. B. McKenzie and F. Shahidi. 2001. Functional properties of protein isolates from beach pea (Lathyrusm aritimus L.). Food Chemistry, 74: 177187.

Chinma, C. E., B. D. Gbabul and O. O. Omotayo. 2012. Quality characteristics of cookies prepared from unripe plantain and defatted sesame flour blends. American Journal of food Technology. 7:7:398-408.

Ciacci, C., L. Maiuri, N. Caporaso, C. Bucci, L. Del Giudice, D. R. Massardo, and M. Londei. 2007. Celiac disease: In vitro and in vivo safety and palatability of wheat-free sorghum. Clinical Nutrition 26: 799-805 
Deora, N.S., A. Deswal and H.N.Mishra. 2014. Alternative approaches towards gluten free dough development. Food Eng. Rev. 6: 89-104

EL-Adawy,T. A. 2002. Nutritional composition and antinutritional factors of chickpeas (Cicer arietinum L.) undergoing different cooking methods and germination. Plant Foods for Human Nutrition57: 83-97.

Fabian, C., and Y. H. Ju. 2011. A review on rice bran protein; Its properties and extraction methods. Critical Reviews in Food Science and Nutrition, 51: 816-827.

Fisher, R. A. 1970. Statistical Method for Research Workers, Eds. Oliver and Boyed, Edinburgh, pp. 140-142.

Gatta, C. D., A. R. Pirgiovann, and P. pervino. 1988. An inproved methods for determination of trypsin inhibitor level of legumes. lebensw-wiss.u. teachnol.21:315-318.

Gimenez, M. A., R. J. Gonzalez, J. Wagner, R. Torres, M. O. Lobo and N. C. Samman. 2013. Effect of extrusion conditions on physicochemical and sensorial properties of corn-broad beans (vicia faba) spaghetti type pasta. Food Chemistry.136:538-545.

Giuberti, G., A. Gallo, C. Cerioli, P. Fortunati, and F. Masoero. 2015. Cooking quality and starch digestibility of gluten free pasta using new bean flour. Food Chemistry $175: 43-49$

Hawa, A., N. Satheesh and D. Kumela. 2018. Nutritional and anti-nutritional evaluation of cookies prepared from okara, red teff and wheat flours. International Food Research Journal 25(5): 2042-2050.

Kupper, C. 2005. Dietary guide lines and implementation for celiac disease. Gastroenterology 128:121-127.

Lee, A.R., D.L. Ng, J. Zivin and P.H.R. Green. 2007. Economic burden of a gluten free diet. Journal of human nutrition and dietetics 20: 423-30.

Masure, H. G., E. Fierens and J. A. Delcour. 2016. Current and forward looking experimental approaches in glutenfree bread making research. Journal of Cereal Science, 67: 92-111.

Mohamed, A., P. J. Perera and Y. Hafez. 1986. New chromosphere for phytic acid determination. Cereal Chem. 63:475-478.

Mohammad, T. A. 2017. Production of high nutritional value cookies from broken rice supplemented with sweet lupin flour. Egypt. J. Agric. Res. 95 (2) :755-767.
Obeidat, B. A., S. S. Abdul-Hussain and D. Z. Al-Omari. 2012. Effect of addition of germinated lupine flour on the physiochemical and organoleptic properties of cookies. J. Food Proc. 37 (5) :637-643.

Ojinnaka, M. C., F. A. Anyanwu and A. Ihemeje. 2013. Nutritional evaluation of cookies produced from African breadfruit (Treculia africana) starch and wheat flour. International Journal Agriculture Food Science. 3:95-99.

Polesi, L. F., S. B. S. Sarmento and C. B. P. Anjos. 2011. Composition and characterization of pea and chickpea starches. Brazilian Journal of Food Technology, 14(1):7481.

Priscila, A., C. Marcio, and S. Manoel. 2015.Gluten-free breakfast cereal prepared with agroindustrial by-products: Physical, chemical, microbiological aspects and sensory acceptance. Food Process Technol 7(1): 533-534.

Rosell, C. M. and R. Garzon. 2015. Chemical composition of bakery products. In: Cheung, P.C.K., Mehta, B.M. (Eds.), Handbook of Food Chemistry. Springer-Verlag, Berlin Heidelberg, pp. 192-222.

Sakac, M., M. Pestoric, A. Misan, N. Nedeljkovi_c, D. Jambrec, P. Jovanov, V. Banjac, A. Torbica, M. HadnCev and A.Mandi_c. 2015. Antioxidant capacity, mineral content and sensory properties of gluten-free rice and buckwheat cookies. Food Technol. Biotech. 53:38-47.

Sharoba, A. M., A. M. Abd El-Salam and H. Hafez. 2014. Production and evaluation of gluten free biscuits as functional foods for celiac disease patients. Journal of Agro alimentary Processes and Technologies 20(3):203214

Sidky, H. M., G. Ranhotra and J. Geltoth. 1991. Nutritional value of wheat: chickpea based weaning food through the use of germination and fermentation. J. Intern. Develop. Res. Center.: 366-373.

Tadele,Y. 2015. Important anti-nutritional substances and inherent toxicants of feeds. Food Science and Quality Management 36: 40-48.

Waller, W. M. and D. B. Duncan. 1969. A Bayes rule for the symmetric multiple comparison problem, J. Am. Statistical Assoc., 64:1484-1499. 


\section{الملخص العربي}

\section{بسكويت مغذي لكرض السيلياك: تأثير خلطات مختلفة من الحبوب والبقول}

حامد مرسي زينة ‘شريف مصباح شمسية ، سعد عزيز محجوب ومحمد عبد الكريم عمارة

هدفت الدراسة الى اعداد وتقييم منتجات بسكويت الحسى. ووفق التحليل الكيماوى كانت نسبة البروتين الخام

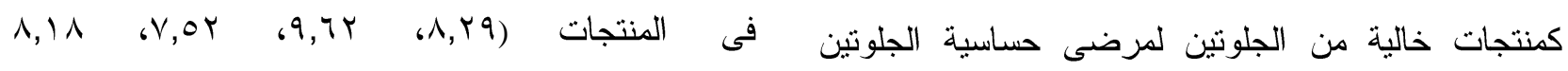

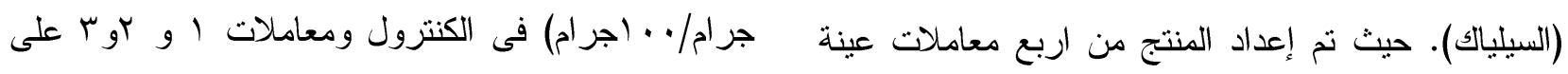
كنترول وثلاث معاملات مختلفة تبعا لمكونات كل معاملة التزتيب. كما اتضح ان إن عنصر البوتاسيوم هو العنصر

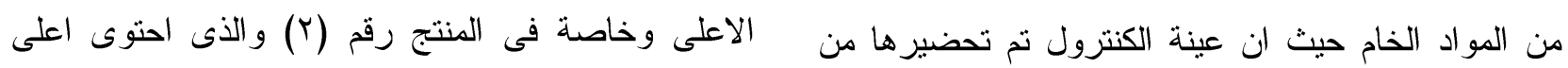

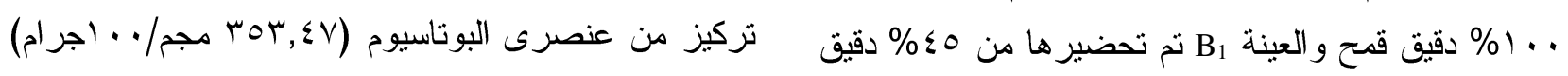

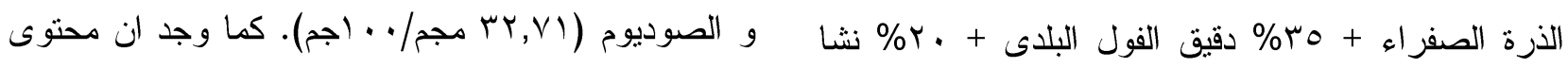

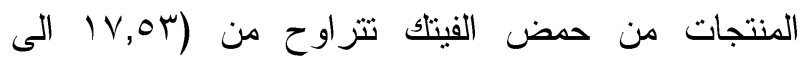

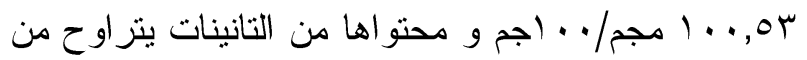

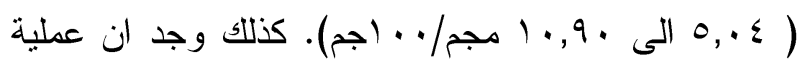
الانبات و المعاملات الحرارية تعمل على زيادة الهضمية الذرة و العينة B2 تم تحضبرها من 0؛

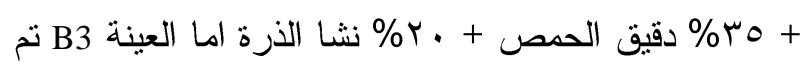

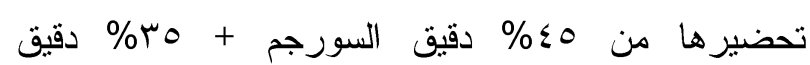
الفاصوليا + + r\% نشا الذرة. المعملية للبروتين وزيادة التقبل الحسى و القيمة التغذوية. تم تقييم التزكيب الكيماوى ومحتواها من العناصر المعدنية وكذلك المواد المضادة للتغذية بالاضافة الى التقييم 